\title{
THE PROTECTION OF THE RIGHT TO STRIKE UNDER THE EUROPEAN CONVENTION ON HUMAN RIGHTS
}

\author{
Charalampos Stylogiannis*
}

\begin{abstract}
The right to strike has been largely acknowledged as an indispensable element of collective bargaining, and as one of the most essential means by which workers can preserve their socio-economic rights. It is safeguarded by international and European human rights instruments, and is enshrined in a number of states' constitutions, including several parties to the European Convention on Human Rights ('ECHR'). Within the legal framework of the ECHR, in the seminal cases of Demir and Baykara $v$ Turkey and Enerji $v$ Turkey the European Court of Human Rights ('ECtHR' or 'the Court') acknowledged the significance of both the right to collective bargaining and to strike as vital features of the freedom of trade unions association, covered by article 11 ECHR. Nevertheless, in RMT $v U K$, the ECtHR mitigated the cause for enthusiasm produced by its previous decisions. This article assesses the extent to which the right to strike is protected in the ECHR by referring to the recent judicial developments within the context of the Convention.
\end{abstract}

\section{A. INTRODUCTION}

'The only thing workers have to bargain with is their skill or their labour. Denied the right to withhold it as a last resort, they become powerless.

The strike is therefore not a breakdown of collective bargaining; it is the indispensable cornerstone of that process.' (Paul Clark, U.S. Labour Historian, 1989)

Let us imagine a legal universe of labour relations where the right to strike would not constitute a legitimate means by which workers can secure fair remuneration and working conditions. The imminent risk involved in such a hypothesis is that we could return to an era of 'sweated labour', ${ }^{1}$ where long hours, low wages, and hazardous working conditions would be inseparable features of the industrial and political sphere. ${ }^{2}$ This scenario is premised on the notion that there is an asymmetry in bargaining power between an employer and a worker, such that 'in the absence of the right to strike, the right to collective bargain is no more than a right to collective begging'. ${ }^{3}$ Fortunately, the description of this society belongs to the past, at least to a certain extent, and hopefully it will remain there.

Contemporarily the right to strike has been broadly acknowledged as an indispensable component of collective bargaining, and simultaneously as one of the most essential means

\footnotetext{
* LLM, University College London. This paper is dedicated to the ones I love the most: My parents Konstantinos and Alexandra, my grandmother Chrariclia, my aunt Martha, and my uncle Aggelos, who was the first to speak to me about the right to strike.

${ }^{1}$ Such working conditions were dominant in Western Europe and other industrialised countries during the $19^{\text {th }}$ century.

${ }^{2}$ Tonia Novitz, International and European Protection of the Right to Strike: A Comparative Study of Standards Set by the International Labour Organization, the Council of Europe and the European Union (OUP 2013) 120.

${ }^{3}$ Keith Ewing and John Hendy QC, 'The Dramatic Implications of Demir and Baykara' (2010) 39 ILJ 10.
} 
by which workers can preserve their socio-economic rights. It is safeguarded by international and European human rights instruments, ${ }^{4}$ and is enshrined in a number of states' constitutions, including many of those which are party to the ECHR. ${ }^{5}$ Despite the fact that this right is not explicitly recognised in any international labour convention, the supervisory bodies of the International Labour Organisation ('ILO') have safeguarded the entitlement to strike by reading it into the provisions of ILO No 87 on the Freedom of Association. ${ }^{6}$ Relying on these specific provisions, the ILO's supervisory bodies have generated substantial caselaw covering the scope and meaning of the right.

These principles have been transferred into the rulings of the ECtHR to a considerable degree. In the landmark cases of Demir and Baykara ${ }^{7}$ and Enerji ${ }^{8}$ the Court recognised the significance of both the right to collective bargain and to strike as vital features of the freedom of association in the form of trade unions, protected by article 11 of the European Convention on Human Rights ('ECHR'). ${ }^{9}$ Such an acknowledgment generated a surge of enthusiasm amongst a plethora of scholars and trade unionists. Ewing and Hendy characterised the case of Demir as an 'epoch making ruling', ${ }^{10}$ while Dorssemont describes the outcome in Enerji as a 'judicial revolution', ${ }^{11}$ due to the 'U-turn' of the Court's approach in relation to the right to strike. It has nevertheless produced an immense debate over the precise extent of the protection of the right to strike. This occurs because national measures restricting its exercise are relatively frequent and extensive. ${ }^{12}$ Within the context of the ECHR such measures have been challenged in many instances before the Court, with the impact of its rulings becoming apparent at the national level of the contracting states. ${ }^{13}$ At the same time, some of the ECtHR's judgments have given rise to a significant amount of

\footnotetext{
${ }^{4}$ See International Covenant on Economic, Social and Cultural Rights (adopted 16 December 1966, entered into force 3 January 1976) 999 UNTS 3 (ICESCR), art 6; European Social Charter (adopted 18 October 1961, entered into force 26 February 1965) ETS 3 (ESC), art 6; European Union Charter of Fundamental Rights [2012] OJ C 326/391 (CFREU), art 28.

${ }^{5}$ See for example Constitution of Greece, art 23(1).

${ }^{6}$ ILO Convention 87 on the Freedom of Association and Protection of the Right to Organise 1948 (adopted 9 July 1948, entered into force 4 July 1950) (ILO Convention 87).

${ }^{7}$ Demir and Baykara v Turkey App no 34503/97 (ECHR, 12 November 2008).

${ }^{8}$ Enerji Yapi-Yol Sen v Turkey App no 68959/01 (ECHR, 21 April 2009).

9 Convention for the Protection of Human Rights and Fundamental Freedoms (adopted 4 November 1950, entered into force 3 September 1953) ETS 5 (ECHR).

${ }^{10}$ Ewing and Hendy (n 3) 41.

${ }^{11}$ Filip Dorssemont, 'How the European Court of Human Rights gave us Enerji to cope with Laval and Viking' in Marie-Ange Moraeu (ed), Before and After the Economic Crisis: What Implications for the 'European Social Model' (Edward Elgar Publishing Limited 2014) 217, 220.

${ }^{12}$ Mimi Zou, 'Freestanding Right or a Means to an End-The Right to Strike in the ILO and EU Legal Frameworks' (2012) 15 TCLR 101.

${ }^{13}$ See for example, Niklas Bruun, 'The Finnish Supreme Court recognizes the impact of European Court of Human Rights case-law on national strike law’ (2011) 17(4) Transfer 577-580.
} 
scholarly literature and reflection regarding the level of protection that has being afforded to the right to strike.

This article seeks to examine, from a human rights perspective, the degree of protection of the right to strike under article 11 ECHR. Section B will assess whether article 11 ECHR offers any possibility for reading into its provisions a general right to strike. It will scrutinise the initial reluctance of the ECtHR to proceed to such an interpretation, and thus to adequately safeguard the right at issue. Section $\mathrm{C}$ will discuss the problematic background from which the Demir and Baykara judgment emerged while considering the case's impact on the protection of the right to strike. Section $\mathrm{D}$ will critically examine the decision in $R M T$ $v U K$, in which the ECtHR appeared to displace any optimism its previous jurisprudence had generated. It will focus on the UK's problematic pre-industrial notices which are necessary for striking workers to escape tortious liability, and on the Court's classification of secondary action as an 'accessory', rather than a core aspect of trade unions' activity. Section E discusses the importance of the right to strike as a human right. It will be argued that its enhanced protection can result in the promotion of human rights for both those taking part in the industrial action and those who are not formally engaged in the dispute. Finally, it will discuss why the ECHR constitutes the 'safest' route through which individuals and trade unions can challenge breaches vis-à-vis the right to strike.

\section{B. THE EUROPEAN COURT OF HUMAN RIGHTS AND THE INTERPRETATION OF ARTICLE 11 OF THE ECHR: THE COURT'S INITIAL RELUCTANCE}

It is true that until relatively recently the ECHR was thought to constitute an instrument for ensuring civil and political entitlements. In the course of adopting its human rights instruments, the Council of Europe drew an apparent distinction between civil and political rights enshrined in the ECHR on the one hand and the socio-economic rights contained in the European Social Charter ('ESC') on the other. Hence, as a socio-economic right, the ECHR does not recognize in any specific way the right to bargain collectively, let alone the right to strike.

As Dorssemont points out, by virtue of this absence, the only prospect for judicial recognition of a right to strike derives from article 11 ECHR, which guarantees the freedom of association in a rather openly-worded form. ${ }^{14}$ This article provides that the right to

\footnotetext{
${ }^{14}$ Filip Dorssemont, 'The Right to Take Collective Action under Article 11 ECHR' in Filip Dorssemont and Klaus Lörcher and Isabelle Schömann (eds), The European Convention on Human Rights and the Employment Relation (Hart 2013) 333, 334.
} 
freedom of peaceful assembly and to freedom of association with others' includes 'the right to form and to join trade unions for the protection of their interests'. ${ }^{15}$ Dorssemont argues that this approach - a generic recognition - essentially differs from the method in which the right to organise is construed in more specialised international instruments. ${ }^{16}$ Within such instruments this right is fleshed out as an entitlement that stems from the freedom of association. ${ }^{17}$ For instance, under the ESC, the right to collective action is interpreted as intertwined with the right to collectively bargain, ${ }^{18}$ while its provision on the freedom of association is silent with regard to collective action/strike. ${ }^{19}$ Having said that and bearing in mind both the non-existence of any stand-alone acknowledgment of a right to strike and the presence of a specific right to form and join a trade union, the question that naturally arises is whether article 11 offers the legal space for reading into its provisions 'a number of corollary rights regarded as inherent aspects of the more generic freedom of association'. ${ }^{20}$ Dorssemont, in considering the wording of the aforementioned provisions, admits that the possibilities for such an evolution are limited. ${ }^{21}$ He stresses that the 'right to form and join a trade union' purely rephrases the key principles of the freedom of association and for that reason the scope of article 11 appears to be construed in a way that covers only the individual, rather than the collective dimension of the right to organise. ${ }^{22}$ This narrow approach generates several concerns in relation to the protection of trade unions' interests, and more specifically to the exercise of the right to collective action.

Fortunately for the protection of human rights, at least within the context of the ECHR, the mere phrasing of a provision does not reveal the whole spectrum of the protection afforded under a particular right. Therefore, in order to assess the status of the right to strike under the ECHR, a thorough examination of the ECtHR's jurisprudence is essential.

\section{The Court's restrictive approach towards the interpretation of article $11 \mathrm{ECHR}$}

As mentioned above the ECHR has, since its inception, been seen as an instrument for ensuring primarily civil and political rights. Even though the official position of the Council of Europe is premised on the very notion of interdependence, indivisibility and interrelation

\footnotetext{
${ }^{15}$ ECHR, art 11.

${ }^{16}$ Filip Dorssemont, 'The Right to Form and to Join Trade Unions for the Protection of his Interests under Article 11ECHR: An Attempt to "to Digest'" the Case Law (1975-2009) of the European Court on Human Rights' (2010) 1 ELJ 186.

17 ibid.

${ }^{18} \mathrm{ESC}$, art 6(4).

${ }^{19}$ ibid art 5; see also ICESCR, art 8; ILO Convention No 87; ILO Convention 98 on the Right to Organise and Collective Bargaining 1949 (adopted 1 July 1949, entered into force 18 July 1951) (ILO Convention 98).

${ }^{20}$ Dorssemont (n 14) 334.

21 ibid 335 .

22 ibid.
} 
of human rights, according to Novitz, there was a notable 'disparity between this rhetorical claim and the actual reality, ${ }^{23}$ regarding the protection of socio-economic rights and in particular the right to strike. During the entire 20th century, the discrepancy between theory and practice was demonstrated by the reluctance of the (then) European Commission on Human Rights ('ECoHR'), and more recently by the ECtHR, to identify 'a hard core of means ${ }^{24}$ that the parties to the Convention should secure in order to permit trade unions to preserve their interests under the scope of article 11 ECHR.

The Court in a number of cases during the 1970s adopted a rather restrictive interpretation, by merely emphasizing that article 11 imposes a duty on contracting states to provide mechanisms that allow trade unions to represent their members; it did not make any particular reference to the methods by which this was to be done. ${ }^{25}$ Consequently, the Court ruled against trade unions which sought to guarantee their interests vis-à-vis the rights to consultation, collective bargaining and strike. ${ }^{26}$ Hendy and Ewing argue that this reluctance can in part be attributed to the existence of the ESC, in relation to which states parties are able to choose freely the specific provisions that they are prepared to accept. ${ }^{27}$ In the early case of National Union of Belgian Police, ${ }^{28}$ it was held that article 6(1) ESC cannot be construed in a manner that gives rise to a 'real right to consultation' and that, even if it did so, this did not mean that article 11 ECHR should be interpreted as such. ${ }^{29}$ The Court relied on the traditional dichotomy between civil liberties and socio-economic rights. ${ }^{30}$ As Novitz rightly points out, it seems doubtful that the drafters of the ESC envisaged that the mechanism would not strengthen the protection of trade unions' interests; rather, it would offer the ECtHR a good reason to construe article 11 in a more protective way. ${ }^{31}$ For instance, The ECtHR had the chance to trace a link between the freedom of association and the right to collectively bargain but did not engage in such considerations.

The approach in National Union of Belgian Police proved to be damaging for trade unions in the process of challenging limitations on the exercise of the right to strike which did not infringe the equal treatment principle. This became apparent in the subsequent case of Schmidt and Dahlström, where state officials and individual members of Swedish trade unions

\footnotetext{
${ }^{23}$ Novitz (n 2) 180.

${ }^{24}$ Dorssemont (n 11) 221.

${ }^{25}$ See Michael Forde, 'The European Convention on Human Rights and Labor Law' (1983) 31 AJCL $301-332$.

${ }^{26}$ See also Swedish Engine Drivers' Union v. Sweden App no 5614/72 (ECHR 2, 6 February 1976).

${ }^{27}$ Ewing and Hendy (n 3) 3.

${ }^{28}$ National Union of Belgian Police v Belgium App no 4464/70 (ECHR, 27 October 1975).

29 ibid [38].

${ }^{30}$ Novitz (n 2) 132.

31 ibid.
} 
tried to challenge the lawfulness of restrictions on the right to strike under article $11 \mathrm{ECHR} .^{32}$ It was held that the right to strike was one of the most important methods by which workers can protect their interests. It went on, however, to add that such a right was by no means the only avenue to do so; there were other ways for the applicants to equally defend their occupational rights. ${ }^{33}$ Plainly, the Court not only treated the right to strike as an important, rather than an essential 'tool' in the hands of workers, but also failed to interpret it as an entitlement 'expressly enshrined in Article 11, ${ }^{34}$ What is surprising with this particular case is that the decision was concluded with reference to the principles protected under both the ILO and the ESC. In addition, the ECtHR's argument relating to alternatives to the right to strike is also open to doubt. Industrial actions are meant to be detrimental for every employer. As Davies states, 'the more harm they cause, the more efficacious they are expected to be in convincing the employer to make concessions. ${ }^{35}$ Thus, alternative means might not be as effective as the act of striking.

Overall, the Court's 'guarded language ${ }^{, 36}$ in its early jurisprudence regarding article 11 constituted an impenetrable barrier for trade unions and individual workers to assert their work-related interests under the Convention. The reluctance of the Court to recognize the importance of the right for the enjoyment of freedom of association appeared to come into contrast with the principles enshrined in other international instruments, like the ESC. Thankfully, cases such as Schmidt and Dahlström appear to have been isolated setbacks and have not been prohibitive with regard to ensuring a more effective protection of collective rights collective rights derived from the ECHR.

\section{Demir and Baykara v Turkey: The 'U-Turn' in the court's jurisprudence}

As Ewing noted, the Court's early case-law with respect to the right to strike meant that few could have foreseen the complainant's success in Demir and Baykara. ${ }^{37}$ But already in 2002 the Court seemed to adopt a considerably divergent approach in UNISON. ${ }^{38}$ There, it was acknowledged for the first time - even though the Court reiterated the mantra that recourse to strike action was simply an important, rather than an essential means to preserve worker's rights - that any constraint on the right to strike 'must be regarded as a restriction on the

\footnotetext{
${ }^{32}$ Schmidt and Dahlström v Sweden App no 5589/72 (ECHR, 6 February 1976).

${ }^{33}$ ibid [33].

34 ibid [36].

${ }^{35}$ Anne Davies 'One Step Forward, Two Steps Back? The Viking and Laval Cases in the ECJ' (2008) 37 ILJ 143.

${ }^{36}$ Dorssemont (n 24) 331.

${ }^{37}$ Keith Ewing, 'The Implications of Wilson and Palmer' (2003) 32 ILJ 3.

${ }^{38}$ UNISON $v$ UK (Admissibility) App no 53574/99 (ECHR, 10 January 2002).
} 
applicant's power to protect [the member's] interests and therefore discloses a restriction ... under the first paragraph of Article 11, ${ }^{39}$ Although the statutory restriction in question was found to be justified under article 11(2) because it pursued a legitimate aim necessary in a democratic society, this shift in jurisprudence constituted a noteworthy development. ${ }^{40}$ The approach in UNISON was adopted in subsequent $\operatorname{cases}^{41}$ and, as Ewing mentions, the right to strike within the context of the Convention emerged as having a bizarre 'twilight status': whilst it was not formally recognised, at the same time, the Court was prepared to recognise the unlawfulness of restrictions on the right regarding article 11(1), which had to be justified under the ambit of article 11(2). ${ }^{42}$

Undoubtedly, this approach appeared much more promising than the one adopted in earlier cases, such as Schmidt and Dahlström. Such a view can also be supported by the Grand Chamber's wording in the subsequent ruling of Wilson and Palmer. ${ }^{43}$ While this case did not concern the right to strike, it is important for a different reason. The ECtHR acknowledged that the right to strike is an essential alternative to force an employer to bargain collectively. ${ }^{44}$ In other words, it was accepted that the right to strike is an important feature of the entitlement to collective bargaining. This interrelationship was demonstrated a few months later, in one of the most significant decisions of the Court in the area of labour rights.

According to Ewing and Hendy, the Court's prior approach was shifted radically in November 2008, in the landmark case of Demir and Baykara. ${ }^{45}$ This significance of this case extended beyond the specific decision, residing in the ECtHR's inclination to re-determine previous authority regarding article 11 by reference to the Convention as a 'living instrument' that has to adapt to societal changes, also emphasising the ability to interpret article 11 in light of other international instruments. ${ }^{46}$

The applicants in Demir and Baykara were members of a Turkish civil service union who entered into a collective agreement that concerned working conditions with a local municipal authority. The latter failed to comply with certain obligations under the agreement and consequently the union brought civil proceedings against it. At first instance, the Turkish

\footnotetext{
39 ibid [37].

40 ibid. See also: Federation of Offshore Worker's Trade Unions and Others $v$ Norway App no 38190/97 (ECHR, 27 June 2002).

${ }^{41}$ See Dilek v Turkey App nos 74611/02, 26876/02 and 27628/02 (ECHR, 30 January 2008).

${ }^{42}$ Dorssemont (n 36) 18.

${ }^{43}$ Wilson, National Union of Journalists v UK App no 30668/96 (ECHR, 2 July 2002)

44 ibid [41].

${ }^{45}$ Ewing and Hendy (n 3$) 3$.

${ }^{46}$ Charles Barrow, 'Demir and Baykara v. Turkey: breathing life into article 11' (2010) 4 EHRLR 420.
} 
District Court found for the union, but its decision was quashed on appeal by the Court of Cassation, ruling that even though civil servants were entitled to join trade unions, the union in question did not have the necessary authority to enter into a collective agreement under domestic law. On second appeal the Court of Cassation reiterated its position by further holding that the trade union did not acquire a legal status due to its failure to comply with prescribed requirements to establish its competences. The union lodged an application before the ECtHR claiming that the Turkish Government was in breach of article 11 ECHR by refusing them the exercise of their entitlements, namely to form a trade union and engage in collective bargaining. Both the Chamber of the Second Section and, at a later stage, the Grand Chamber unanimously held that the Turkish authorities were in breach of article 11 'on account of the interference with the right of the applicants, as municipal civil servants, to form a trade union [and] of the annulment ex tunc of the collective agreement entered between the trade union, following collective bargaining with the employing authority'. ${ }^{47}$ Distancing itself from its previous jurisprudence, the Court explicitly recognised that the right to bargain collectively is an inherent feature of article 11 ECHR. In doing so, as Lörcher argues, 'it opened up the whole Convention to a more socially oriented interpretation'. ${ }^{48}$

As stated, the significance of the case lies in the approach adopted by the Strasbourg Court. It implemented a living instrument/evolutive interpretation by relying on a consolidated approach to construing the ECHR in light of other international instruments and common practices amongst the member states of the Council of Europe. ${ }^{49}$ The Court emphasized that the scope and content of article 11 could be determined by using relevant international treaties, ${ }^{50}$ irrespective of whether a respondent member had actually ratified that particular international instrument. ${ }^{51}$ Indeed, in the course of assessing if the right to

\footnotetext{
${ }^{47}$ Demir and Baykara (n 7) [183].

${ }^{48}$ Klaus Lörcher, 'The New Social Dimension in the Jurisprudence of the European Court on Human Rights (ECHR): The Demir and Baykara Judgment, its Methodology and Follow-up' in Filip Dorssemont and Klaus Lörcher and Isabelle Schomann, The European Convention on Human Rights and the Employment Relation (Hart 2013) 4.

49 ibid 5.

${ }^{50}$ Ewing and Hendy (n 3$) 6$.

${ }^{51}$ Demir and Baykara (n 7) [66]. It may be questionable as to whether such an approach is compatible with customary rules on treaty interpretation. As a multilateral treaty the ECHR constitutes part of public international law, and thus it is governed by the principles enshrined in the Vienna Convention on the Law of Treaties 1969 (VCLT). However, according to scholars such as Pieter van Dijk and others (Pieter Van Dijk and others, Theory and Practice of the European Convention on Human Rights (Kluwer Law International 1998) 72) the principles of the VCLT do not offer clear solutions to all the problems emerging from treaty interpretation. The ECHR cannot be considered as a traditional treaty of 'reciprocal nature' concluded to generate only horizontal obligations between the contracting states. The Convention as a human rights treaty possesses a special standard-setting character which lies in the fact that states assume obligations (vertical in a sense) to safeguard individuals' fundamental rights. Consequently, due to the particular nature of the Convention, the Court has developed other interpretative approaches to bridge the gaps. One of these is the 'living-instrument'
} 
collective bargaining could be read into article 11, special reference was made to international labour principles and relevant case-law; especially ILO Convention 98, article 6 ESC and article 28 European Union Charter of Fundamental Rights ('CFREU'). All these instruments contain similar language regarding the protection of trade unions. ${ }^{52}$

It is arguable that the living instrument espoused by the Court is not novel; it was not the first time it referred to international standards or to the jurisprudence of relevant bodies. It is recalled that in the case of Schmidt and Dahlström the verdict was reached by reference to ILO standards and the requirements of the ESC. Interestingly enough, the same stance had been adopted in other earlier cases touching upon social and economic rights. ${ }^{53}$ In Demir and Baykara, the Court affirmed the well-established notion that 'the Convention is a livinginstrument ... which must be interpreted in the light of present-day conditions' ${ }^{54}$ This approach offers the Court the opportunity to protect a wider range of fundamental rights, which the Convention's drafters may not have thought to secure at the time, or even rights they intentionally chose to omit. ${ }^{55}$ Through this approach, the Court has inter alia necessitated the legal recognition of the new identity of post-operative transsexuals; ${ }^{56}$ prohibited practices denying maternal affiliation upon birth to children born out of wedlock; ${ }^{57}$ and recognized the right not to be obliged to join a trade union. ${ }^{58}$

This of course requires us to ask what was 'exciting' about the Court's approach in Demir and Baykara? The answer can be found in Lörcher's analysis. He argues that the innovative characteristic of the case is the "consolidation of the interpretation method based on a systematic and unprecedented breakdown of the related international labour standards'.59 He proceeds to comment that, normally, where the Court interpreted rights enshrined in the Convention, it used to rely on the living-instrument approach construing rights in a way that renders them 'practical and effective, not theoretical and illusory' ${ }^{60}$. However, the systematic reliance on external instruments gave the Court's methodological approach a novel

\footnotetext{
doctrine that seeks to protect a wider range of fundamental rights, which the Convention's drafters would not have thought to secure at the time, or even rights that they intentionally chose to omit.

${ }^{52}$ ILO Convention 98; ESC, art 6; CFREU, art 28.

${ }^{53}$ See Siliadin v France App no 73316/01 (ECHR, 26 October 2005).

${ }^{54}$ Tyrer $v$ United Kingdom App No 5856/72 (ECHR, 25 April 1978) [31].

55 For a thorough analysis of the 'living-instrument' approach see George Letsas, 'The ECHR as a Living Instrument: Its Meaning and its Legitimacy' (March 2012)

<papers.ssrn.com/sol3/papers.cfm?abstract_id=2021836> accessed 07 August 2016.

${ }_{56}^{56}$ Goodwin v United Kingdom App no 17488/90 (ECHR, 27 March 1996).

${ }^{57}$ Marckx v Belgium App no 6833/74 (ECHR, 13 June 1979).

${ }^{58}$ Young, James, Webster $v$ United Kingdom App no 7601/76 (ECHR, 13 August 1981).

${ }^{59}$ Lörcher (n 48) 10.

${ }^{60}$ ibid.
} 
dimension. ${ }^{61}$ Thus, the new approach lies in the words 'systematic and unprecedented consolidation'. Never before had the Grand Chamber dedicated so much time and space in the course of acknowledging the specific role played by instruments such as ILO Conventions and the ICESCR in an overall 'internationally friendly interpretation'. ${ }^{62}$ Accordingly, 'the ESC and ILO fora were no longer procedures for promulgating grievances and causing some gentle diplomatic embarrassment for domestic authorities, rather they constitute authoritative instruments that the Court will look upon in interpreting article 11 ECHR., ${ }^{63}$

Even though the ruling in Demir and Baykara generated a wave of enthusiasm amongst workers and trade unions, it also created concerns regarding the legitimacy and the limits of the Court's interpretation, as a treaty-based authority. For instance, Jacobs maintains that in its future jurisprudence regarding the right to collective bargaining, the Court should not aim at a harmonisation of the domestic legislation on collective bargaining, since industrial structures between the Council of Europe member states are essentially nonequivalent, having emerged from diverse historical backgrounds; hence, certain aspects of trade union interests should be left to the discretion of national authorities. ${ }^{64}$ Of course such an argument cannot be considered as an actual disagreement with the Court's ruling, but rather as an acknowledgment of the existing difficulties towards a uniformity of industrial relations based on relevant international standards.

Moreover, it has been stressed by the Turkish authorities ${ }^{65}$ that the Court went too far in its application of the living-instrument approach, and accordingly in its social construction of the ECHR. This statement is based on the notion that the primary objective of the Convention concerns the protection of civil and political entitlements. Such an argument is highly unconvincing. Apart from the fact it is against the very notion of the indivisibility and interrelation of human rights, no limitation whatsoever is to be traced in the Preamble of the Convention, which prohibits such a 'social interpretation'. ${ }^{66}$ As O'Cinneide states, ever since the case of Airey $v$ Ireland, ${ }^{67}$ the Court has both recognized the 'permeability' of civil/political

\footnotetext{
61 ibid.

62 ibid.

${ }^{63}$ Ewing and Hendy (n 3) 6.

${ }^{64}$ Antoine Jacobs, 'Article 11 ECHR: The Right to Bargain Collectively under Article 11 HER' in Filip Dorssemont and Klaus Lörcher and Isabelle Schomann, The European Convention on Human Rights and the Employment Relation (Hart 2013), 314-315.

${ }^{65}$ See for example the Turkish Government's Preliminary Objections in (n 7) [53]-[58].

${ }^{66}$ The first and the second recitals of the ECHR's Preamble make an explicit reference to the Universal Declaration of Human Rights, which makes no distinction between human rights.

${ }^{67}$ Airey v Ireland App no 6289/73 (ECHR, 9 October 1979).
} 
and social rights and the Convention's social dimension. ${ }^{68}$ The Court often applies what Mantouvalou calls, an 'integrated' approach when interpreting conventional rights; ${ }^{69} \mathrm{a}$ method predicated on the interdependence and indivisibility of human rights. Civil and political rights cannot be fully enjoyed if socio-economic norms are not preserved; it would be socially unjust and seemingly unprincipled for the Court to adopt a dynamic interpretation towards specific rights and not to do the exact same thing with respect to other entitlements. After all, as Sir Nicolas Bratza puts it, due to the Court's evolutive interpretation, 'the Convention becomes not a dead letter, but the vital and living-instrument it was always supposed to be'. ${ }^{70}$

\section{THE IMPLICATIONS OF THE JUDGMENT IN DEMIR AND BAYKARA V TURKEY ON THE RIGHT TO STRIKE}

Jacobs mentions that 'for the evolutive interpretation, the sky is the limit'. ${ }^{71}$ The Court, with its decision in Demir and Baykara seemed to embrace this view, despite accusations of 'judicial activism'. It was confirmed for the first time that the right to collective bargaining, in principle, is one of the vital elements of the right to form and to join a trade union. In doing so, it paved the way for equal protection with respect to other forms of trade union activity, particularly the right to strike. ${ }^{72}$

The Court's evolutive interpretation approach became apparent once more, some weeks later, in Enerji Yapi-Yol Sen. In that case, individuals employed in the public sector were banned from participating in a national one-day strike organised to defend collective bargaining rights. The Second Section of the Court, relying on the methodological framework set out in Demir and Baykara re-iterated the view that 'strike action, which permits a trade union to express their concerns, is an essential feature in the protection of trade unions' members interests' ${ }^{73}$ It went on to state that the right to collective action is protected by international specialised instruments, such as the ILO Convention $87,{ }^{74}$ and despite the fact it is not an absolute entitlement due to the permissibility of certain restrictions under article

\footnotetext{
${ }^{68}$ Colm O'Cinneide, 'The Social Dimension of ECHR Rights: escaping the Dead Hand of Orthodoxy' in Josep Casadevall and Nicole Lehner and Natalie Donath (eds), Mélanges en l'honneur de Dean Spielmann - Essays in Honour of Dean Spielmann (Wolf Legal Publishers 2015) 330.

${ }^{69}$ Virginia Mantouvalou, 'Labour Rights in the European Convention on Human Rights: An Intellectual Justification for an Integrated Approach to Interpretation' (2013) 13 HRLR 529.

${ }^{70}$ Sir Nicolas Bratza, 'Living-instrument or dead letter - the future of the European Convention on Human Rights' (2014) 2 EHRLR 119.

${ }^{71}$ Barrow (n 60) 310.

${ }^{72}$ Ewing and Hendy (n 3) 2.

${ }^{73}$ Enerji Yapi-Yol Sen (n 8) [24].

${ }^{74}$ ibid.
} 
11(2) ECHR, an indiscriminate prohibition is an undoubtedly illegitimate and disproportionate act. So, according to Fabbrini, it is now confirmed that the right to collective bargaining and the right to collective action constitute 'two sides of the same coin': trade unions are awarded with actual bargaining power only to the extent to which they have the choice to strike action to bolster their assertions; in that way, preservation of a right to bargain collectively by necessity implies protection of the right to collective action. ${ }^{75}$

Not even some of the most optimistic legal practitioners could have predicted the Court's labour-friendly departure from its previous line of jurisprudence in the decisions in National Union of Belgian Police and Schmidt. Yet, a flaw in the Enerji decision can be said to exist in the Second Chamber's hesitation to qualify the right to strike as constituting an essential aspect in the protection of the interests of trade unions, rather than merely an important facet thereof. Writing at that time, Ewing and Hendy describe this position as purely explanatory of the fact that there are other means by which trade unions can safeguard their 'well-being'. ${ }^{76}$ This disinclination could be more problematic than it may seem at first. This is related with the limitations permitted on the right to strike under the scope of article 11(2) ECHR. Particularly, it could be argued that the Court may be prepared to conduct more intense scrutiny when examining prohibitions or limitations placed upon essential trade union activities, as opposed to merely important means. Equally, restrictions and bans on an alleged essential method could be perceived less 'necessary' in a democratic society. In fact, this semantic difference can prove detrimental to the protection of the right to strike, as becomes evident below.

Nevertheless, after its decision in Enerji, the Court continued to embrace its labourfriendly path in subsequent cases; the position of trade unions and individual workers within the context of the Convention was enhanced, especially in those contracting states currently endowed with a very obstructive regulation of the right to strike. This was apparent in two rulings against the same state, namely Saime Özcan v Turkey ${ }^{77}$ and Kaya and Seyhan $v$ Turkey. ${ }^{78}$ Both cases concerned public servants who were sanctioned in different ways due to their participation in strike actions. In Saime Özcan, a school teacher was prosecuted for having abandoned her workplace and was sentenced to three years and ten days imprisonment, commuted to a substantial fine; in Kaya and Seyhan two secondary school teachers received disciplinary warnings. The two cases can be distinguished in relation to the

\footnotetext{
${ }^{75}$ Federico Fabbrini, Fundamental Rights in Europe (OUP 2014) 142.

${ }^{76}$ Ewing and Hendy (n 3) 11-12.

${ }^{77}$ Saime Özcan v Turkey App no 22943/04 (ECHR, 15 September 2009).

${ }^{78}$ Kaya and Seyhan v Turkey App no 30946/04 (ECHR, 15 September 2009).
} 
harshness of the sanction, as consequences for Ms Özcan were much more severe than the sanctions for the other two applicants. In both instances, the Court did not hesitate to repeat that a disproportionate interference with trade union freedom of association constitutes an infringement of article $11 \mathrm{ECHR}$, even where it is simply capable of discouraging individual workers and trade unions from taking part in industrial action. ${ }^{79}$ Especially in Kaya and Seyhan the Court seemed to depart from prior judgments such as UNISON: relatively less onerous restrictions on the right to strike were not justified under article 11(2) of the Convention. This, however, does not suggest that all related actions taken by an employer will constitute a violation of article $11 .^{80}$ Still, the various developments were unpredictable.

The significance of the recent judicial developments regarding labour entitlements under the Convention lies in the explicit recognition of the right to collective action; a right inextricably linked to the right to bargain collectively. Without a doubt, this acknowledgment signifies a great improvement in the preservation of European collective rights. This is to say that trade unions and individual workers no longer need to prove that they do not have any alternatives to protect their interests, as an interference with the right to collective action alone suffices in order to trigger article 11 ECHR protection.

Before proceeding to the next section, the following briefly summarises some of the main concerns in relation to the Court's construction of article 11 ECHR with regard to what may prove detrimental for the protection of the workers' right to strike. First, as indicated, the Court left the question as to whether such a right constitutes an essential rather than an important facet of article 11 open after Enerji. Its reluctance to give a clear answer to this question could lower the protection of collective action. In addition, it generates the following confusion: while the right to collective bargaining is an 'essential' feature of article 11 , the right to strike is merely protected as an important element thereof. This hardly makes sense, as the Court has also accepted the right to strike as the corollary to collective bargaining. So why does the Court persist in not giving an answer to this inconsistency?

This issue is related to a second set of concerns, namely, the disagreement vis-à-vis the status of the right to strike within the ILO's instruments. It is now well-established that the standards enshrined within the ILO's jurisprudence to a substantial extent have been transferred into the decisions of the ECtHR. As mentioned, Convention 87 does not encompass any reference to the right to strike and from the history of its development it can

\footnotetext{
79 ibid [30]; see also Danilelenkov v Russia App no 67336/01 (ECHR, 30 July 2009); Urcan and Others v Turkey App no 23018/04 (ECHR, 17 July 2008).

${ }^{80}$ For example the non-payment of remuneration for the days that a worker participates in a strike action.
} 
be stated that the negotiating states deliberately embraced this omission. ${ }^{81}$ Despite this absence, the ILO's supervisory bodies, namely the Committee of Experts ('CoE') and the Committee on the Freedom of Association ('CFA') have now read the right to strike into the texts of Convention $87,{ }^{82}$ by consistently emphasizing that it is inherent to the right to freedom of association covered under the ILO; a position that has been confirmed by Strasbourg.

As Velyvyte asserts, in reacting to the 'activism' of the supervisory bodies, the ILO's Employer's Group has repeatedly challenged that the right to strike is enshrined in Convention $87 .^{83}$ They argue that even though it is plausible to interpret Convention 87 as protecting the right to strike, nevertheless, the CoE and the CFA should not infer - due to its initial absence - from the text of Convention 87, 'a global, precise and detailed, absolute and unlimited right [to strike] ${ }^{84}$ The conflict climaxed in 2012, during the International Labour Conference when the Employer's Group refused to engage in any discussion on some of the most serious breaches involving the right to collective action; hence the Conference's procedures 'fell into the abyss'. ${ }^{85}$

Let us contend that such disputes within the most specialised-authoritative UN institution concerning labour rights could also have a negative effect as far as the relevant jurisprudence of the ECtHR is concerned. This occurs because the Court's dynamic interpretation is and will continue to be based upon the status of the right to strike within the ILO Convention. ${ }^{86}$ Accordingly, the absence of consensus concerning the scope of the latter's protection could also call into question the legal basis of the ECtHR's interpretation and in turn its own credibility as a human rights court. As such, it could be assumed that the Court's reluctance to qualify the right to strike as 'essential' for the purposes of article 11 ECHR can be, amongst other reasons, attributed to the internal disputes within its main authoritative source with regard to labour entitlements. Detrimental consequences for the protection of the right to strike materialized from these concerns in the recent case of $R M T v U K,{ }^{87}$ where the Court seemed to temper its position on the preservation of the right to collective action.

\footnotetext{
${ }^{81}$ Bernard Gernigon and Alberto Odero and Horacio Guido, 'ILO Principles Concerning Collective Bargaining' (2000) 139 ILR 45.

82 ILO Convention 87.

${ }^{83}$ Vilija Velyvyte, 'The Right to Strike in the European Union after Accession to the European Convention on Human Rights: Identifying Conflict and Achieving Coherence’ (2015) 15 HRLR 79, 80-81.

${ }^{84}$ ibid 81 .

${ }^{85}$ ibid.

86 ibid.

${ }^{87}$ National Union of Rail, Maritime and Transport Workers v United Kingdom App no 31045/10 (ECHR, 8 April 2014).
} 


\section{THE CASE OF RMT V UNITED KINGDOM: THE 'HANGOVER' OF THE EUROPEAN COURT OF HUMAN RIGHTS?}

Hangovers and blackouts can reduce the ability of the brain to form long-term memories. The causes are more or less well-known and no further explanation is needed. It would be fair to ask how the word 'hangover' relates to the ECtHR and its jurisprudence. Professor Ewing employed this word, likening the ruling of the $R M T$ case to a person that experiences the effects of 'hangover'. ${ }^{88} \mathrm{He}$ explained that the Court seemed to have partially forgotten its previous promising jurisprudence. Indeed, the Court in $R M T$ appeared 'to misplace the optimism' the cases of Demir and Enerji generated, ${ }^{89}$ in a highly problematic judgement regarding the protection of the right to collective action.

The case involved two specific issues, namely the complex balloting provisions trade unions have to comply with before a strike action takes place, and the blanket ban of secondary or solidarity strike actions. Before examining this case in more depth, some information with respect to the status of the right to strike in the UK is useful. In the UK there has never existed any positive right to strike or other similar actions, and any such act has always been potentially unlawful at common law, under one or other of the 'economic torts', like conspiracy or inducement to breach a contract. ${ }^{90}$ In other words, as Maurice Kay LJ emphasized, this right in the UK 'has never been more than a slogan or a legal metaphor. What has happened is that ... legislation has provided limited immunities from a liability in tort'. ${ }^{91}$ Consequently, industrial action might be restricted by an injunction brought by the employer, who may also be able to claim damages for their losses. That said, one might argue that the ECtHR would be less tolerant towards the UK's strike laws which have been constantly the subject matter of criticism by authoritative labour law institutions, like the ILO and ESC. ${ }^{92}$ Likewise, the Court's stringent approach in a series of cases against Turkey, another state with many restrictions on strike law, was relatively fresh.

Yet, as Bogg and Ewing assert, Strasbourg seemed to give with the one hand and take with the other: even though it reiterated that the right to strike is clearly protected under

\footnotetext{
${ }^{88}$ Keith Ewing, 'Seminar: The Fundamental Rights Discourse - Council of Europe Mechanisms - The European Social Charter', 20 November 2015, King's University.

${ }^{89}$ Charles Barrow, 'RMT v. United Kingdom [2014]: The European Court of Human Rights Intimidated into Timidity or Merely Consistent in its Inconsistency?’ (2015) 3 EHLR 277.

${ }^{90}$ Ian Smith and Aaron Baker, Smith \& Wood's Employment Law (11th edn, OUP 2013) 687.

${ }^{91}$ Metrobus v UNITE [2009] EWCA Civ 829 (Maurice Kay LJ).

92 ILO Convention 98; ESC, art 6.
} 
article $11 \mathrm{ECHR}$, the decision reduced the scope of its protection. ${ }^{93}$ As stated, the case concerned two specific complaints. In relation to the pre-industrial notices that are necessary in escaping tortious liability, RMT members sought to challenge the granting of an injunction to inhibit their union from calling industrial action. At issue was the trade union's failure to act in accordance with the ballot notice provisions, which required the union to give to the employer sufficiently detailed information on the groups of those workers expected to participate in the strike action. This failure resulted in the employer being awarded an injunction permitting him to restrict the strike action. The union corrected its initial mistake and after re-balloting it gave to the employer its renewed notice. The collective action ultimately took place. The Court, 'in a sole paragraph striking for its briefness', ${ }^{94}$ found that this complaint was 'manifestly ill founded', ${ }^{95}$ hence this limb of the claim was deemed inadmissible. It asserted that the union was not restrained as far as the strike action was concerned; it did not suffer any loss, and therefore no breach of article 11 of the Convention occurred. ${ }^{96}$ Disappointingly, as Barrow emphasizes, the Court's superficial analysis resulted in its failure to engage in any consideration of the injunction's impact on the activities of the trade union. ${ }^{97}$

It is contended that the Court's attitude in this regard was problematic for various reasons. First, as a matter of fact, the effects of the injunction were detrimental in the sense that the union incurred costs of $£ 87,000$ to defend its actions in domestic courts. ${ }^{98}$ It had also suffered a considerable delay while the re-balloting procedure took place, depriving the union of its initial tactical advantage. ${ }^{99}$ Secondly, as a matter of law, the Court's 'poor' explanation appeared to come into contrast with its previous jurisprudence on the restrictions on the right to strike. It is recalled that in the earlier case of Kaya and Seyhan a disciplinary warning to two secondary school teachers was considered as discouraging the applicants from engaging in a one day strike action; hence, it was not justified under the restrictions of article 11(2) ECHR. Furthermore, in the pre-Demir case of Wilson, it was held that the relevant industrial law of a state should not dissuade workers from using their trade union to represent them for matters regulating their relations with their employers. ${ }^{100}$ Still, in $R M T$ the obstacles imposed

\footnotetext{
${ }^{93}$ Alan Bogg and Keith Ewing, 'The Implications of the RMT Case' (2014) 43 ILR 221.

94 ibid 231.

${ }^{95}$ RMT (n 86) [45].

96 ibid.

${ }^{97}$ Barrow (n 88) 278.

${ }^{98} R M T$ (n 86) [53].

${ }^{99}$ ibid.

${ }^{100}$ Barrow (n 88) 232.
} 
upon the trade union were not deemed sufficient to trigger the applicability of article 11(1). As Ewing and Bogg argue, it is difficult to understand how 'the labyrinthine notice provisions conditioning the legality of strike action in the UK, along with the costs and the practical disadvantages followed due to the injunction, did not constitute an impediment discouraging the union's ability to safeguard its members' interests'. ${ }^{101}$ It is indeed peculiar that a disciplinary warning in Kaya and Seyhan had not been justified under article 11(2), whilst the restrictions at issue could not fall within article 11(1). It will not come as a surprise therefore that the Court, once again, avoided qualifying the right to strike as an essential aspect of article 11. This may be deemed indicative of the fact that the Court's reluctance is not purely descriptive as to the existence of other methods by which trade unions can protect their interests, as previously discussed. If, in its earlier case-law, the Court had seized the opportunity to qualify the right to strike as an essential rather than an important feature of article 11, it is possible that the UK's legislative restrains on industrial action would more likely be construed as violating the Convention.

The second aspect of the case concerned the removal of tortious immunity from industrial action in solidarity (or sympathy). In particular, some of the trade union's members, working for Fastline Ltd (part of the Jarvis plc group), were transferred to Hydrex Equipment Ltd, in order to perform the exact same job (rail engineering), with terms conserved under Transfer of Undertakings (Protection of Employment) Regulations 2006 ('TUPER'). ${ }^{102}$ The problems arose as soon as their protection under TUPER expired; as a result, their remuneration reduced to the levels of other workers in the enterprise. Although they went on strike, they were unable to persuade the employer to address their concerns due to their lack of industrial power - just 20 members strong. What was even more frustrating for the transferred workers was that the trade union they belonged to was unable to call for a secondary action either at Fastline Ltd, or Jarvis plc, in order to support them at Hydrex; s 224 of the Trade Union and Labour Relations (Consolidation) Act 1992 provides that all solidarity actions are unlawful. As such, any attempt to resort to sympathy action would have render the statutory immunities inapplicable. ${ }^{103}$ Thus, the trade union initiated proceedings before the ECtHR, claiming that the domestic regulations on secondary strikes had a 'chilling effect' on their power to protect its transferred workers.

\footnotetext{
101 ibid.

102 Transfer of Undertaking (Protection of Employment) Regulations 2006, SI 2006/426.

103 Trade Union and Labour Relations (Consolidation) Act 1992.
} 
To begin with the 'labour-friendly' aspect of the case, the ECtHR acknowledged the existence of an implicit right to secondary action which is preserved under the ambit of article 11. In coming to this conclusion, the Court referred to other international instruments and the decisions of international supervisory bodies, as well as common practices of the ECHR's states parties. For instance, both the provisions of the ILO and ESC enshrine this right as part of the wider right to strike. ${ }^{104}$ But the Court classified it as an 'accessory' rather a core feature of trade unions' right to associate thereby reducing the level of protection afforded to it. ${ }^{105}$ A wider margin of appreciation was given to the UK in the determination of the issue under article 11(2). The UK authorities stressed that solidarity strikes should be strictly limited, because they could potentially damage the economic recovery of the country by disrupting its economic process. ${ }^{106}$ In seeking to justify this, the UK also cited statistics in relation to the negative financial impacts the strike caused, but it did not proceed to any division between primary and secondary action. Barrow argues that the information given by the government was highly unconvincing since there was no proof that the consequences of the action in question were so detrimental for third parties and the economy as a whole. The Court accepted these arguments and found that the blanket prohibition of secondary actions was proportionate and necessary in a democratic society in pursuing the legitimate aim of preserving the rights and freedoms of others not engaging in the dispute. In other words: although the UK's blanket ban on secondary action was a very restrictive measure compared with the position in other parties of the Convention, that it did not by itself indicate that in regulating this aspect of trade union activity it had inevitably exceeded its wide margin of appreciation. ${ }^{107}$ Thus, this interference did not violate the right to strike.

It is surprising that the ECtHR accepted the UK's arguments and upheld a wide margin of appreciation. It did not examine the costs that a blanket prohibition could have on the trade unions' legitimate activity to protect the interests of their members, especially when they are participating in industrial action and supplementary pressure is a useful bargaining tool. In doing so, as Barrow mentions, the Court disposed of two key factors that have played a prominent role in its previous jurisprudence: the conformity of the measure with European labour standards and the principles deriving from related international instruments. ${ }^{108}$ It argued that the assessment of the legal matters was particular to the circumstances of the

\footnotetext{
${ }^{104} R M T$ (n 86) [26]-[37].

105 ibid [77].

${ }^{106}$ Paul Gragl, 'The Right to Secondary Industrial Action under the ECHR and International Human Rights Law' (2014) 1 JICL 5.

107 Barrow (n 88) 280.

108 ibid.
} 
case; the supervisory bodies' approach regarding the ban on secondary action was not persuasive, as the issue was examined only in exceptional situations. ${ }^{109}$ It was held that the ILO's jurisprudence was limited to situations where the ban of solidarity actions was deemed to make it easier for the employers to take advantage of the law in question. ${ }^{110}$ This could occur "where there is a very high degree of proximity between a "primary" and a "secondary" employer (for example, by outsourcing work to another enterprise)'. ${ }^{111}$ According to the Court this scenario did not apply to the very facts of RMT; Hydrex Enterprise Ltd and Jarvis Ltd were genuinely distinct entities and as such there was no 'abuse' of powers on the employer's part.

Bogg and Ewing characterised these findings as 'unsupportable', due to the Court's restrictive interpretation. ${ }^{112}$ They argued that the ILO's supervisory bodies have also espoused a broader approach regarding the protection of solidarity action by highlighting its importance in situations where it has been used to assist foreign workers to secure their entitlements, or in supporting multi-employer collective bargaining. ${ }^{113}$ Thus, it could be stated that the Court adopted a 'pick and choose' stance, by construing the ILO's jurisprudence in a rather restrictive manner. Such behaviour comes into contrast to the approach adopted in Demir and Enerji where the principles enshrined in international supervisory bodies had been construed in an expansive way based on their systematic breakdown. At this point, Ewing's 'hangover' characterization is relevant. The Court seemed to forget its labour-friendly approach and, in 'light of the breadth of the margin of appreciation in this area, ${ }^{114}$ it paid lip service to the principles and jurisprudence of specialised institutions.

Yet, this was not the only problem as far as the ruling is concerned. As seen, the Court has classified secondary action as an 'accessory' rather than a core aspect of trade unions' activities. It is true that this distinction resembles to a certain extent the division that has been drawn with respect to the primary right to strike within the Convention, ie it is an important, rather than essential feature of article 11 ECHR. Having already expressed a view on the latter distinction, it is arguable that the legal implications for characterising secondary action

\footnotetext{
${ }^{109} R M T(\mathrm{n} 87)$ [98].

110 ibid.

${ }^{111}$ Bogg and Ewing (n 92) 241.

112 ibid.

113 ibid.

${ }^{114}$ John Hendy QC and Michael Ford QC, 'RMT v United Kingdom: Sympathy Strikes and the European Court of Human Rights' (Oxford Human Rights Hub, 10 April 2014) <ohrh.law.ox.ac.uk/rmt-v-united-kingdomsympathy-strikes-and-the-european-court-of-human-rights/> accessed 18 August 2016
} 
as an 'accessory' are indeed problematic as they indicate the narrow scope of protection afforded. The term 'accessory' can be defined as something which 'contributes to or aid an activity or process in a minor way; subsidiary or supplementary. ${ }^{115}$ While it would be difficult for someone to disagree over the definition of the word, many have expressed their dissent regarding the categorisation of solidarity actions as 'accessorial' to the rights to bargain collectively and strike. For instance, it has been said that solidarity has been central to the philosophy of both the socialist and labour movements. ${ }^{116}$ Within the labour context this has been confirmed by the International Trade Union Confederation which adopted a Declaration of Principles that inter alia states: 'The Confederation ... is committed to provide practical solidarity to all in need of it, and to confront the global strategies of capital with global strategies of labour. ${ }^{, 17}$ This is also apparent as many of the European states reserve some space of legality for secondary actions in their labour policies, apart from the UK of course. ${ }^{118}$ As such, solidarity actions should be extended as widely as possible to rightholders and particularly to those individuals who have been excluded from the enjoyment of their entitlements. After all, solidarity within secondary actions is one of the most important words in the language of the workers and its restricted protection within the Court's jurisprudence is indeed problematic for an effective protection of the right to strike. But what is even more worrying is the Court's general approach in $R M T$.

Several concerns exist. The most significant relate to the future protection of the right to strike within the ECHR. The Court's rulings in the Demir and Enerji cases are recent and well-established, but their 'legacy' neither prevented the Court from finding against the problematic UK's balloting provisions in $R M T$, nor anticipated offering a narrow protection regarding secondary actions. Thus, in considering the outcome in $R M T$, some might stress that the protection of the right to strike within the legal framework of the Convention can be inadequate. The next section will engage with such considerations by highlighting the importance of the right to strike for human rights in general.

\section{E. THE IMPORTANCE OF THE RIGHT TO STRIKE AS A HUMAN RIGHT AND ITS FUTURE PROTECTION UNDER THE ECHR: AN ENHANCED OR SUPERFICIAL PROTECTION?}

\footnotetext{
${ }^{115}$ Oxford Dictionaries <www.oxforddictionaries.com/definition/english/accessory> accessed 18 August 2016.

${ }^{116}$ Kate Cook, 'Solidarity as a basis for human rights: Part 2: "practical solidarity"' (2012) 6 EHRLR 654.

${ }^{117}$ Constitution of the International Trade Union Confederation, adopted at the Founding Congress, Vienna, November 2006 <www.ituc-csi.org/IMG/pdf/Const-ENG-W.pdf> accessed 18 August 2016.

${ }^{118}$ Lord Weddeburn, Labour Law and Freedom (Lawrence and Wishart 1995) 276.
} 
It has long been acknowledged that labour rights are human rights, ${ }^{119}$ 'even though the human rights movement and the labour movement run on tracks that are sometimes parallel and scarcely meet'. ${ }^{120}$ As Leary points out, historically, trade unions and other labour rights institutions inclined to monopolising inquires of workplace justice, while human rights organisations tended to focus instead on political and civil rights matters. ${ }^{121}$ Nonetheless, the tracks have recently started to converge with trade unionists and labour lawyers now using the rhetoric of human rights to enhance their claims. Collective labour rights are enshrined as individual rights in human rights treaties but as seen 'are there with the purpose to assist people pursue collective and solidaristic objectives' ${ }^{122}$ This is also the case with the right to strike.

Much of the discussion regarding the protection of the right to strike has been concentrated on its impact on workers' interests. It is undeniably an essential facet of the right to freedom of association, as without it the right to collective bargaining would be a rather 'weak' process, where the employer would have the upper hand in determining the working rules and conditions. Its primary function is the promotion of social and political entitlements enshrined in international human rights law. This for instance includes the right to decent remuneration; strike action can also be carried out to ensure that their right to safe and healthy working conditions is respected. ${ }^{123}$

Still, the impact of industrial actions is not confined to situations where purely labour interests are at stake. As Ewing states, many of the significant right to strike cases in domestic courts are identified as human rights cases, even though they are not articulated as such. ${ }^{124}$ Notably, in some of these cases the right to strike was brought to the fore as the means of giving effect to the enjoyment of civil and political rights. For example, this has become apparent in instances where the right to freedom of conscience was involved (by rejecting the idea to undertake obligations that offend the worker's conscious beliefs), ${ }^{125}$ or in cases where the freedom of expression was exercised (as a means of expressing support or

\footnotetext{
119 See Virginia Mantouvalou, 'Workers' Rights Really Are Human Rights' (Open Democracy, 21 October 2014) <www.opendemocracy.net/openglobalrights/virginia-mantouvalou/workers\%E2\%80\%99-rights-reallyare-human-rights $>$ accessed 19 August 2016.

${ }^{120}$ Virginia Leary, 'The Paradox of Worker's Rights as Human Rights' in Lance Compa and Stephen Diamond (eds), Human Rights, Labor Rights and International Trade (University of Philadelphia Press 1996) 22.

121 ibid.

${ }^{122}$ Hendy QC and Ford QC (n 114).

${ }^{123}$ According to the Social Rights Committee of the Council of Europe has to be at least $60 \%$ of the average male wage.

${ }^{124}$ Keith Ewing, 'Laws Against Strikes Revisited' in Catharine Bernard and Simon Deakin and Gillian Morris (eds), The Future of Labour Law: Liber Amocorum Bob Hepple QC (Hart 2004) 41, 50-51.

${ }^{125}$ BBC v Hearn [1977] ICR 685 (CA).
} 
opposition to a specific method implemented either by the government at issue or the employer). ${ }^{126}$ This is not to imply that all strike actions have the purpose of promoting human rights when the employment conditions at issue transgress the minimum standards set out by international instruments. Nevertheless, as Ewing claims, in situations where national laws and practices fail to fulfil these duties, 'it is hard to deny that a strike to increase the standards of some workers to these international minimum prerequisites is an industrial action designed to promote and establish human rights' ${ }^{127}$ In the absence of any legislative obligation imposed on the employer, strike action might be the only resort for individuals and trade unions to safeguard the human rights that their government failed to enforce, despite its international obligations. ${ }^{128}$ This underlines the importance of qualifying the right to strike as a human right.

Finally, the importance of the right to strike can be illustrated through a third perspective, which is equally important. Particularly, the effects of a strike action can be expanded to human rights holders who are not taking part in the action in question, ie to third parties. This can occur where one group of workers may go on strike in an attempt to secure the reinstatement of workers fired due to their trade union activity; or where a trade union may boycott a specific place of work because it discriminates between domestic and migrant workers. In both situations the element of solidarity is essential for the promotion of human rights. Thus, both primary and secondary strike actions play a vital role in the comprehensive protection of the right to strike.

To summarise, in view of the significance of the right to strike, it could be stated that its adequate protection could have as a result not only the protection of those formally engaged in the dispute but also the preservation of the rights and freedoms of others. The question that then arises is whether the ECtHR can rely on the legacy of Demir and Enerji to adequately protect such rights, or whether the most recent developments of $R M T$ case render these expectations impossible?

\section{The current developments and the increasing 'hostility' towards labour rights: The ECtHR as the guardian of the right to strike?}

At the European level, workers are now entitled to organise strikes with the view of preserving their economic, social and union-related interests. In recent years, the ECtHR's contributions to this have been remarkable, although not flawless. However, in many respects

\footnotetext{
${ }^{126}$ Express Newspapers $v$ Keys [1980] IRLR 247 (CA).

${ }^{127}$ Leary (n 120) 51.

128 ibid 52.
} 
the battle is not yet over. The right to strike cannot be seen solely through a Convention standpoint, but needs to be assessed in accordance with the current (neo)liberal developments in the European terrain.

What began as a meltdown of the global financial system during the period of 200708 has now taken the form of a new economic and political reality of austerity policies, which according to many commentators jeopardizes the enjoyment of human rights generally, and socio-economic rights in particular. ${ }^{129}$ Indeed, since 2010, austerity has become the 'only game in town'. ${ }^{130}$ The present-day attention is on new economic governance activities and the subjection of labour rights in general to more closely coordinated national economic arrangements. The latter have been presented as part of the Europe 2020 growth strategy, with the scrutiny and surveillance of national economies. ${ }^{131}$ Perhaps the greatest impact of these measures is the coordinated attack on collective bargaining structures and as an immediate result on strike actions. For instance, the levels of strike activity in the UK in recent years have fallen to their lowest for over a century; ${ }^{132}$ in Finland, after the crisis was declared, the number of illegal strikes has soared; ${ }^{133}$ while in Greece the recent Law $3899 / 2010$ creates a number of additional requirements regarding industrial actions that can only be met by trade unions with great difficulty. ${ }^{134}$ Although a full account of the consequence of the financial crisis on the right to strike is beyond the scope of this article, it can be stated that the plethora of measures adopted by the majority of European states poses a real threat to the enjoyment of workers' entitlements and consequently to the right to strike.

Apart from the detrimental effects of the 'great recession' on industrial actions, the treatment of the right to strike by the EU has also been problematic and contested. As Novitz argues, within the EU 'the trend has been towards not positive protection, but rather the exercise of EU powers to negate access to strike actions. ${ }^{, 135}$ She argues that this may be a

129 Mary Dowell-Jones, 'The Sovereign Bond Markets and Socio-Economic Rights: Understanding the Challenge of Austerity' in Eibe Riedel, Gilles Giacca and Christopher Golay (eds), Economic, Social and Cultural Rights in International Law: Contemporary Issues and Challenges (OUP 2014) 51, 51-52.

${ }^{130}$ Kees van Kersbergen and Barbara Vis and Anton Hemerijck, 'The Great Recession and Welfare State Reform: Is Retrenchment Really the Only Game Left in Town?' (2014) 48(7) SPA 884.

${ }^{131}$ Keith Ewing, 'The Death of Social Europe' (2015) 21 KLJ 87.

${ }^{132}$ Leary (n 120) 42.

133 Stefan Clauwaert and Isabelle Schomann, 'The Crisis and National Labour Law Reforms: A Mapping Exercise' (2012) European Trade Union Institute Working Paper, 10

$<$ www.etui.org/content/download/6097/58601/file/The+crisis +and+national+labour+law+reforms + Country+by +country.pdf $>$ accessed 21 August 2016.

133 ibid.

134 See Aristea Koukiadaki and Lefteris Kretsos, 'Opening Pandora's Box: The Sovereign Debt Crisis and Labour Market Regulation in Greece’ (2012) 41 ILJ 276.

${ }^{135}$ Tonia Novitz, 'The EU and the Right to Strike: Regulation through the Back Door and its Impact on Social Dialogue’ (2016) 27 KLJ 47. 
response to the fact that workers' industrial activity can reduce the exercise by market entities of the commercial freedoms under the Treaty on the Functioning of the European Union ('TFEU'). ${ }^{136}$ This became apparent in the infamous Viking ${ }^{137}$ and Laval cases. ${ }^{138}$ Despite acknowledging the significance of strike actions as a means of preserving workers' interests, the Court of Justice ('CJEU') held that such a right could and needed to be balanced against the commercial principles of the European economic institution. Consequently, the right to strike was constrained in a manner unprecedented in the domestic constitutional orders. By applying a proportionality test which asked whether the economic freedoms enshrined in EU law could be justifiably limited by the right to strike, the CJEU seemed to be prioritising economic freedoms over fundamental rights. ${ }^{139}$ Thus, where collective actions are at stake, it seems to depart from the principle provided in article 53 CFREU which provides that: 'Nothing in this Chapter shall be interpreted as restricting or adversely affecting human rights and fundamental freedoms as recognised ... by Union law and International Law ...', including article 11 ECHR. ${ }^{140}$ According to Davies, this reflects the fact that the CJEU regards its own role as one of preserving and encouraging the Community's laws fundamental principles which include economic freedoms. ${ }^{141}$

Although briefly analysed, the current developments within the European context appear to be somewhat hostile towards the exercise of the right to strike. The current austerity measures implemented as a response to the financial crisis, along with the problematic rulings of the CJEU pose an immediate threat on the enjoyment of the right in question. For this reason, many authors have stressed that accession of the EU to the ECHR, as required by article 6(2) Treaty on European Union ('TEU'), ${ }^{142}$ might offer an enhanced protection for human rights, including for the right to strike. Yet the CJEU's Opinion 2/13 - which found the draft agreement for accession incompatible with EU law - indicates that this will not take place any time soon. So where does this leave the protection of the right to strike?

The ECtHR should be, and has the potential to be, the 'guardian' of this right. The rulings in Demir and Enerji constitute the best demonstration of this. These ground-breaking decisions were celebrated not solely by Turkish trade unions but also by a plethora of workers and human rights advocates across Europe. It might be argued that the ECtHR has

\footnotetext{
136 ibid.

${ }^{137}$ Case C-438/05 International Transport Workers' Federation v Viking Line ABP [2007] ECR I-10779.

${ }^{138}$ Case C-341/05 Laval un Partneri Ltd v Svenska Byggnadsarbetareforbundet [2007] ECR I-11767.

${ }^{139}$ For a thorough analysis of the case see $n 82$.

${ }^{140}$ CFREU, art 53.

${ }^{141}$ Davies (n 35) 147.

${ }^{142}$ Consolidated Version of the Treaty on European Union [2008] OJ C115/13, art 6(2).
} 
diminished cause for such celebrations in $R M T$, raising doubts as to whether it had regretted its previous decisions. Nonetheless, this may not be the case. Recently, in Hrvatski Lijecnicki Sindikat, ${ }^{143}$ it was held (in a concurring opinion) that the right to strike constituted the "the most powerful instrument of trade unions to protect their occupational interests of their members' ${ }^{144}$ Thus, it essentially acknowledges the right to strike as an essential facet of article 11 ECHR. The shift from the Court's stance in RMT might be explained as a consequence of extra-judicial considerations. Jacobs states that the Convention 'has come into dire straits over the past number of years, and the case law of the ECtHR is no longer the subject of widespread appreciation'. ${ }^{145}$ Some decades ago, labour lawyers discouraged their clients from bringing their claim on the right to strike in front of the ECtHR. This is not the case anymore. The Strasbourg Court, regardless of errors, can be perceived as the 'guardian' of human rights, including the right to strike.

\section{F. CONCLUSION}

This article has sought to provide a systematic analysis of the right to strike as protected by the ECHR. This analysis is premised on the suggestion that the right to strike constitutes one of the most essential means by which workers can safeguard their interests. Initially the ECtHR failed to recognise such a right, generating a sense of despair among trade unions and labour lawyers. However, in the landmark Enerji case, the Court effectively reversed its stance and, by relying on international specialised instruments like the ILO Conventions 87 \& 98, has now acknowledged that the right to strike is inextricably linked to the right to bargain collectively; hence, it is protected under the Convention. But the Court hesitated to qualify the right to strike as an essential rather than a merely important aspect for the protection of the interests of trade unions. This enabled the decision in $R M T$ which raised questions regarding the level of protection afforded to the right to strike.

The recent case of Hrvatski Lijecnicki Sindikat provided some clarification: the right in question was held to be the most essential means in the hands of trade unions in preserving their members' work-related interests. It thus demonstrated, it is submitted, that the Court can comprehensively protect the right to strike. In the context of economic crises and the CJEU's hostile approach to industrial action, such protection is all the more necessary. It remains to

\footnotetext{
${ }^{143}$ Hrvatski Lijecnicki Sindikat v Croatia App no 36701/09 (ECHR, 27 November 2014).

144 ibid Concurring Opinion of Judge Pinto De Albuquerque, [10].

${ }^{145}$ Antoine Jacobs, 'Hrvatski Lijecnicki Sindikat v. Croatia Secondary Industrial Action' (2015) 1 ILRCL 92.
} 
be seen whether the ECtHR will continue, by relying on the legacy of Demir and Enerji, to maintain its enhanced protection of the right to strike.

(C) [2017], The Author(s). This is an Open Access article distributed under the terms of the Creative Commons Attribution License (CC-BY)

4.0 https://creativecommons.org/licenses/by/4.0/, which permits unrestricted use, distribution, and reproduction in any medium, provided the original author and source are credited. 